\title{
Agroindustrial Evaluation of Sugarcane Varieties in the Central Zone of Veracruz, Mexico
}

\author{
Daniel Rolando Martínez-Torres ${ }^{1}$, Cesáreo Landeros-Sánchez ${ }^{2}$, Alejandra Soto-Estrada ${ }^{2}$, Gustavo López-Romero², \\ Bladimir Vela-Lara ${ }^{1} \&$ Juan Carlos Moreno-Seceña ${ }^{3}$ \\ ${ }^{1}$ Centro de Bachillerato Tecnológico agropecuario No. 17, Prolongación Pípila No. 1828, El Ciruelo, Mpio. de \\ Úrsulo Galván, Veracruz, México \\ ${ }^{2}$ Colegio de Postgraduados, Campus Veracruz, Km. 88.5 Carretera Federal Xalapa-Veracruz, vía Paso de Ovejas \\ entre Puente Jula y Paso San Juan, Tepetates, Veracruz, México. C.P., Apartado Postal 421 Veracruz, Ver. C. P., \\ México \\ ${ }^{3}$ Instituto Tecnológico Superior de Martínez de la Torre. Asesor Técnico de la SEV. Km. 4.5 Carretera Federal \\ Xalapa-Veracruz, Col. SAHOP, C.P., Xalapa, Veracruz, México \\ Correspondence: Cesáreo Landeros-Sánchez, Colegio de Postgraduados, Campus Veracruz, Km. 88.5 Carretera \\ Federal Xalapa-Veracruz, vía Paso de Ovejas entre Puente Jula y Paso San Juan, Tepetates, Veracruz, México. \\ C.P., Apartado Postal 421 Veracruz, Ver. C. P., México. Tel: 52-229-201-0770. E-mail: clandero@colpos.mx
}

Received: October 17, 2012 Accepted: October 31, 2012 Online Published: December 13, 2012

doi:10.5539/jas.v5n1p147

URL: http://dx.doi.org/10.5539/jas.v5n1p147

\begin{abstract}
The use of sugarcane varieties having high agroindustrial production, that are resistant to primary pests and diseases and are well adapted to regional conditions is a key factor for increasing the yield of this crop. The objective of this study was to agronomically and industrially evaluate a set of 12 sugarcane varieties in terms of their planting and ratoon cycles. This investigation used methodological protocols developed by the Instituto para el Mejoramiento de la Producción de Azúcar (IMPA) (Institute for the Improvement of Sugarcane Production) to assess the agroindustrial potential of new varieties. The 12 varieties were evaluated by testing them under the same management and climate conditions. An experimental design of completely randomized blocks and three replicates was used. Yield $\left(\mathrm{t} \mathrm{ha}^{-1}\right)$ and sucrose content (\%) were assessed. There were no significant differences for yield $(\mathrm{p}>0.05)$ with regard to planting cycle. Control variety Q-96 had the highest sucrose content (15.95\%). For the ratoon cycle, the highest yield corresponded to variety L 73-65 with $178 \mathrm{t} \mathrm{ha}^{-1}$, and the lowest value was for variety HA 64-20 having $107 \mathrm{t} \mathrm{ha}^{-1}$. Variety Mex 91-662 had the greatest sucrose content $(17.66 \%)$ and its yield $\left(171 \mathrm{t} \mathrm{ha}^{-1}\right)$ shows that this variety has great promise for the sugarcane zone supplying the El Modelo refinery and for the state of Veracruz.
\end{abstract}

Keywords: Saccharum officinarum L., varieties, production, sucrose

\section{Introduction}

Sugar is one of the most consumed products in the world simply by being an important component in the human diet. In many countries of Latin America and Asia, sugarcane (Saccharum officinarum L.) cultivation performs an important function by generating jobs and income for the population.

According to the International Sugar Organization (ISO), (2011), the world production of sugar for the 2010-2011 harvest was 165.83 million tons and Mexico contributed 3.2\% of this production. The cultivation of sugarcane has economic and social importance in Mexico; it generates jobs and income for approximately 440,000 families, located in 227 municipalities in 15 states, ultimately benefiting 2.5 million Mexicans. The state of Veracruz is the main sugarcane producer, having 22 sugar refineries (from 57 existing in the country), contributing $36 \%$ of the national production (SAGARPA, 2009).

Even when the Instituto para el Mejoramiento de la Producción de Azúcar (Institute for the Improvement of Sugar Production, IMPA) released varieties with wide adaptive potential that have been cultivated in Mexico and other countries, the low production of sugarcane was primarily the result of the lack of varieties adapted to a wide range of physical conditions, soil types, climates and biological conditions (Díaz et al., 2003; Julca \& Fava, 2011; Sánchez, 1997). 
By the end of 1990, the genetic improvement programs for sugarcane in Mexico were not articulated. Genetic improvement in this crop requires at least 10 to 12 years to obtain the seed that produces the variety that is delivered to producers. Therefore, generating new sugarcane varieties having greater productivity is one of the main reasons for preserving and improving this crop. As a consequence of the genetic improvement research carried out from 1970 to 2000, more than 50 Mexican varieties of good agroindustrial quality were obtained and covered 400,000 ha $(62 \%$ of the commercially cultivated surface area). Some outstanding varieties found were Mex 57-473, Mex 68-P-23, Mex 69-290 and Mex 79-431 (Flores, 2001).

The productivity of the sugarcane crop depends chiefly on the genetic value of the varieties (Rubio, 1997; Sánchez, 1997; Zerega et al., 2002). As such, the selection and evaluation of varieties should be a permanent and systematic process that guarantees the availability of new and improved genotypes for the sugarcane agroindustry, for variety replacement or diversification. Thus, the objective of this study was to agroindustrially evaluate a set of 12 sugarcane varieties with regard to their planting and ratoon cycles.

\section{Materials and Methods}

This study was carried out from 2005 to 2008 in the experimental field at the Centro de Bachillerato Tecnológico agropecuario No. 17 (C.B.T.a. No. 17) in the municipality of Úrsulo Galván, located $34 \mathrm{~km}$ from the port city of Veracruz and $70 \mathrm{~km}$ from the capital city of Xalapa. It is located at $19^{\circ} 22^{\prime} \mathrm{N}$ and $95^{\circ} 25^{\prime} \mathrm{W}$ at 8 masl, is enclosed in a region having climate type $\mathrm{Aw}_{2}$, an annual precipitation of $1350 \mathrm{~mm}$, an average relative annual humidity of $80 \%$ and an average monthly temperature of $25^{\circ} \mathrm{C}$. The primary soil types are loamy silt-sand and sand-silt. The $\mathrm{pH}$ of these soils is slightly acidic, with values between 5.5 and 6.8 (Flores et al., 2011).

Twelve varieties (treatments) were evaluated: MY 55-14, HA 64-20, Q-96 (control), Mex 69-290 (control), CP 72-2086 (control), L 73-65, Mex 91-566, Mex 91-662, Mod Mex 93-404, Mod Mex 93-412, Mod 95-401 and Mod 95-4191; the controls were varieties already cultivated in the study zone. An experimental design of randomized complete blocks was used with three replicates over a $2808 \mathrm{~m}^{2}$ area. The size of each plot was 4 rows $10 \mathrm{~m}$ long and $1.3 \mathrm{~m}$ wide, equaling $52 \mathrm{~m}^{2}$.

The experimental units had the same management plan: 1) fertilization with 200-51-110 kg ha ${ }^{-1}$ of $\mathrm{N}, \mathrm{P}$ and $\mathrm{K}$, respectively. The commercial components for the fertilizer were urea (46-0-0), potassium chloride (0-0-60) and the mixture 'triple 17' (17-17-17); 2) six irrigations were applied over two cultivation cycles of the crops studied, with an approximate depth of $12 \mathrm{~cm}$ each; 3) weed control was carried out manually and chemically using the pre-emergent herbicide ametrina (Gesapax combi $80 \mathrm{ph}$ ), and the post-emergent herbicide ametrina $+2-4 \mathrm{D}$ amina (Gesapax H); both at doses of $4 \mathrm{~kg}$ and $4 \mathrm{~L} \mathrm{ha}^{-1}$ and diluted in $400 \mathrm{~L}$ of water.

The response variables measured in the field were yield $\left(\mathrm{t} \mathrm{ha}^{-1}\right)$ and sucrose content (\%). These variables were considered the two most valuable according to the methodology developed by IMPA (1988). Yield was measured at the moment of crop harvest in each experimental unit, as it is traditionally done in the area of study. The harvest was weighed using a $200 \mathrm{~kg}$ capacity scale.

The percentage of sucrose was determined in the laboratory at the El Modelo refinery using the Pol / Sucrose Ratio (where the apparent sucrose content is expressed as a mass percent measured by the optical rotation of polarized light passing through a pure sucrose solution) for which 13 stems were sampled at random from each treatment (Fonseca et al., 2006). The stems of each sample were chopped prior to homogenization, and each of the samples labeled. From each sample a subsample of $400 \mathrm{~g}$ was weighed out and blended in $1 \mathrm{~L}$ of water for 5 $\min$. Then the liquid was decanted and the fiber washed, pressed and weighed. The diluted juice was then poured into a $250 \mathrm{~mL}$ test-tube, into which a refractometer (Brix Meter) and a thermometer were placed, and was then left to rest $1 \mathrm{~min}$ before reading. Polarization was accomplished by filtering $100 \mathrm{~mL}$ of diluted juice into a 250 $\mathrm{mL}$ precipitation glass to which $1 \mathrm{~g}$ of lead subacetate was added and the mixture was agitated vigorously. This mixture was filtered and placed in a polarimeter to obtain a corresponding value of percentage of sucrose.

Statistical assessment was carried out using an analysis of variance (ANOVA) on yield and the averages were compared using a Tukey test $(\mathrm{p} \leq 0.05)$. The software package Experimental Designs version 2.5 was used (Faculty of Agronomy, Universidad Autónoma de Nuevo León, México) (Olivares, 1996).

\section{Results and Discussion}

\subsection{Yield}

Results for the sugarcane varieties in terms of yield for each plot for planting cycle 2006-2007 are shown in Table 1. 
Table 1. Yield for the sugarcane varieties in planting cycle 2006-2007

\begin{tabular}{ccc}
\hline Number of Treatments & Variety & Yield $\left(\mathrm{t} \mathrm{ha}^{-1}\right)$ \\
\hline 3 & Q-96 & $195.1 \mathrm{a}$ \\
9 & Mod Mex 93-404 $^{\mathrm{C}}$ & $190.1 \mathrm{a}$ \\
5 & CP 72-2086 & $187.1 \mathrm{a}$ \\
4 & Mex 69-290 & $185.6 \mathrm{a}$ \\
11 & Mod Mex 95-401 & $185.3 \mathrm{a}$ \\
8 & Mex 91-662 & $183.9 \mathrm{a}$ \\
2 & MY 55-14 & $181.3 \mathrm{a}$ \\
12 & JA 64-20 & $178.3 \mathrm{a}$ \\
6 & Mod Mex 95-419 & $172.4 \mathrm{a}$ \\
7 & L 73-65 & $171.1 \mathrm{a}$ \\
\hline
\end{tabular}

$\overline{\mathrm{C}}=$ Control; Yield values with the same letter indicate no significant differences $(\mathrm{P}>0.05) ; \mathrm{CV}=10 \%$.

The analysis of variance on harvest yield showed no significant differences among the varieties. However, yields were superior to the average production for the zone supplying the El Modelo refinery $\left(100 \mathrm{t} \mathrm{ha}^{-1}\right)$ (PRONAC, 2009). The varieties in this study that are not controls are thus important alternatives for the diversification of sugarcane in the supply zone.

Yield presented considerable variability among planting and ratoon cycles. The differences depended strongly on the genetic characteristics of the varieties, the climatic conditions, management of the crop, and that the harvesting was carried out according to maturation curves to maximize the concentration of sucrose in the plants (Díaz et al., 2003).

Table 2 presents the yield for each experimental plot in ratoon cycle 2007-2008.

Table 2. Yield of the sugarcane varieties during ratoon cycle 2007-2008

\begin{tabular}{ccc}
\hline Number of Treatments & Variety & $\begin{array}{c}\text { Yield } \\
\left(\mathrm{t} \mathrm{ha}^{-1}\right)\end{array}$ \\
\hline 6 & L 73-65 & $178 \mathrm{a}$ \\
8 & Mex 91-662 & $171 \mathrm{a}$ \\
4 & Mex 69-290 & $168 \mathrm{a}$ \\
1 & MY 55-14 & $166 \mathrm{a}$ \\
9 & Mod Mex 93-404 & $156 \mathrm{a}$ \\
5 & CP 72-2086 & $155 \mathrm{a}$ \\
10 & Mod Mex 93-412 & $154 \mathrm{a}$ \\
12 & Mod Mex 95-419 & $150 \mathrm{ab}$ \\
3 & Q-96 & $150 \mathrm{ab}$ \\
11 & Mod Mex 95-401 & $138 \mathrm{ab}$ \\
7 & Mex 91-566 & $136 \mathrm{ab}$ \\
2 & JA 64-20 & $107 \mathrm{~b}$ \\
\hline
\end{tabular}

$\mathrm{C}=$ Control; Yield values with different letters are statistically different $(\mathrm{p} \leq 0.05) ; \mathrm{CV}=10.23 \%$. 
In this ratoon cycle and for this variable, the analysis of variance and the Tukey means comparison test showed significant differences (Table 2). Varieties L 73-65, Mex 91-662, Mex 69-290 (control) and MY 55-14 had yields over $160 \mathrm{tha}^{-1}$.

Varieties L 73-65 and Mex 91-662 surpassed the control varieties in this study. Variety L 73-65 was the only one that increased its yield with respect to the previous cycle, which can be attributed to the good below-ground shoot development of its cutting/rootstalk. Control variety Q-96 had the highest yield during the first planting cycle; but from all varieties it did not have the greater yield during this cycle; it declined by $45.1 \mathrm{t} \mathrm{ha}^{-1}$.

Rubio (1997) found that for clay soils, which predominate in the supply zones for the refineries La Gloria and El Modelo in Veracruz, the variety Mex 69-290 had the best yield. This finding parallels the results from this study, where this variety had one of the better yields (185.6 and $168 \mathrm{tha}^{-1}$ in the first planting and ratoon cycles).

Variety JA 64-20 showed the lowest yield for this cycle $\left(107 \mathrm{t} \mathrm{ha}^{-1}\right)$, and when comparing the planting and ratoon cycle data, this variety had the most reduced yield $\left(71.3 \mathrm{t} \mathrm{ha}^{-1}\right)$. In contrast, variety Mex 91-566 showed the smallest decrease in yield $\left(10 \mathrm{t} \mathrm{ha}^{-1}\right)$; a product of its genetic potential and its interaction with the environment (Rea \& De Sousa, 2001).

It is also important to mention that yields for the planting cycles fluctuated between 146.1 and $195.1 \mathrm{t} \mathrm{ha}^{-1}$, and from 107 to $178 \mathrm{t} \mathrm{ha}^{-1}$ for the ratoon cycles. These values are superior to the performance average in the supply zone $\left(100 \mathrm{t} \mathrm{ha}^{-1}\right)$ for the El Modelo refinery. Thus, the use of these varieties in the supply zone is justified because of the economic and social benefits derived from the higher yields of these varieties.

\subsection{Sucrose Content}

The sucrose content (\%) in the varieties studied for the planting cycles are presented in Figure 1. The highest contents corresponded with varieties Q-96 (control), Mod Mex 95-419 and Mex 91-662 which contained 16.62, 15.95 and $15.49 \%$. Variety Mex 91-566 had the lowest content (10.45\%). Oviedo et al. (1999) found similar results when evaluating, for one planting cycle, nine varieties of sugarcane, including Q-96. This variety had the highest sugar content.

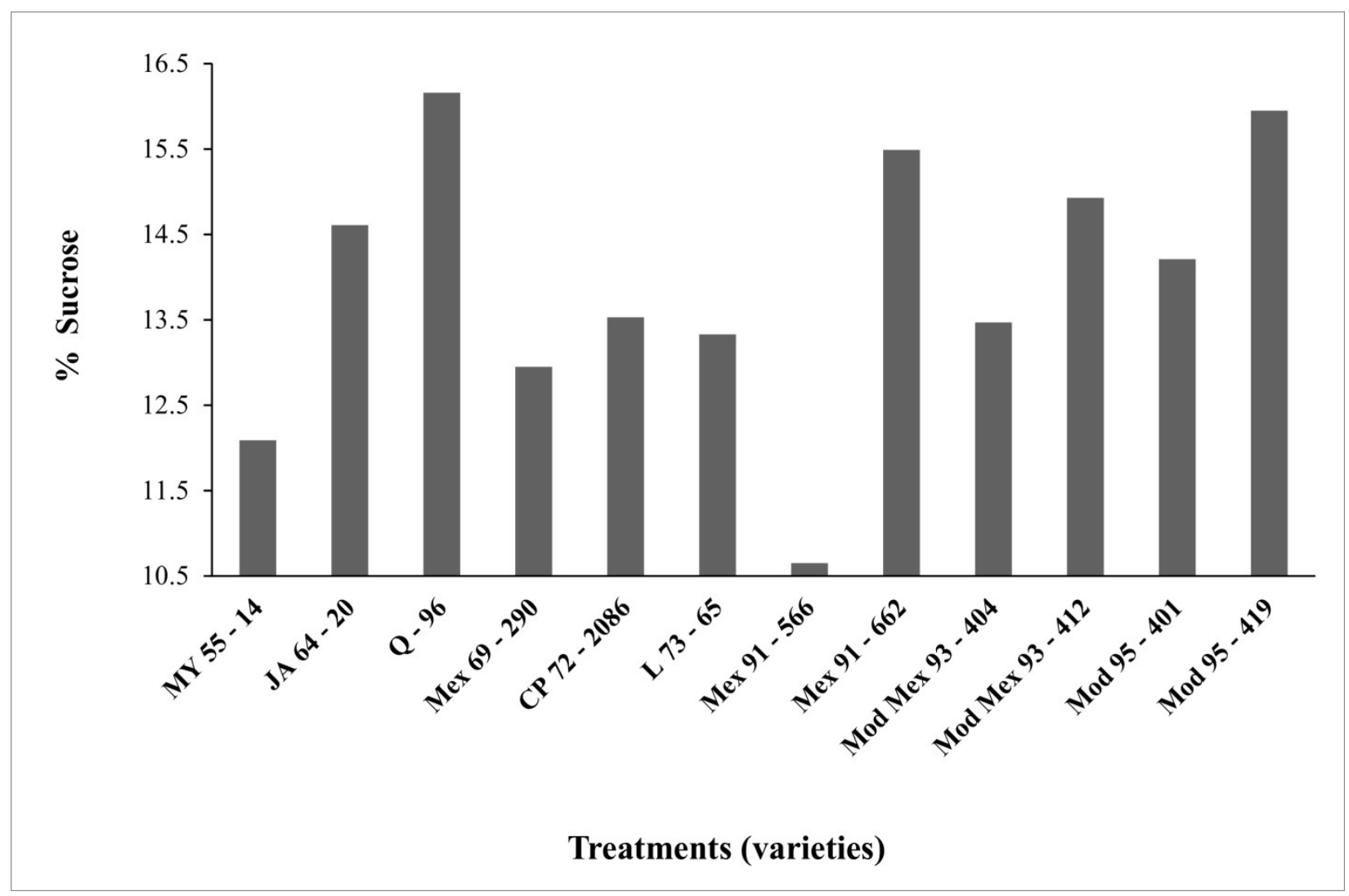

Figure 1. Sucrose content (\%) from each variety (treatment) of sugarcane during planting cycle 2006-2007 
Figure 2 shows the sucrose content (\%) obtained from the ratoon cycle. The highest values were registered in varieties Mex 91-662, JA 64-20, CP 72-2086 (control) and Mod 95-401, with 17.66, 16.24, 15.83 and 15.82\%, respectively. The majority of the varieties increased their sucrose content compared to values observed for the planting cycle.

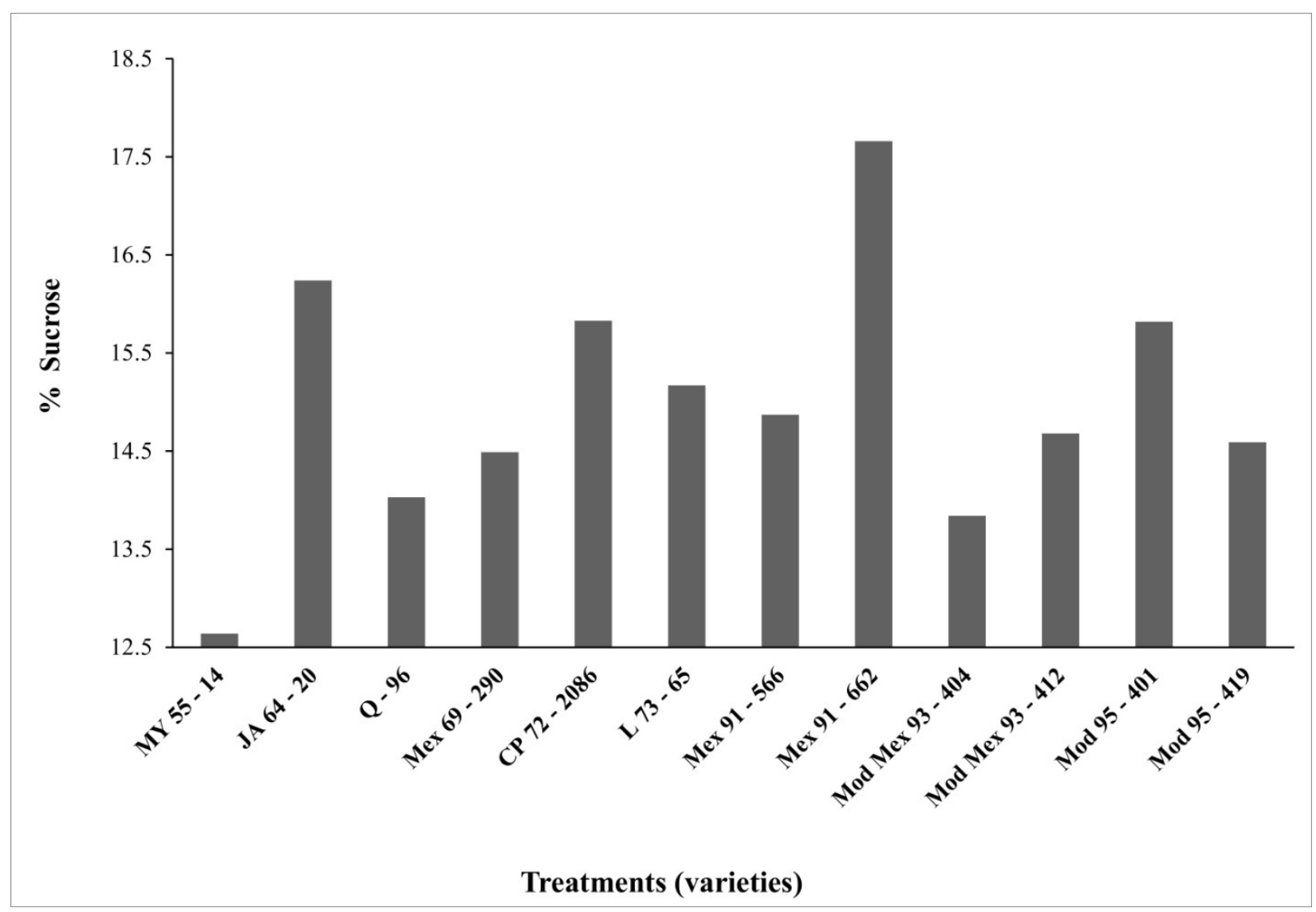

Figure 2. Sucrose content (\%) among the sugarcane varieties (treatments) during ratoon cycle 2007-2008

A criterion for selecting sugarcane varieties is that they have more than $16 \%$ sucrose or that this percentage be equal to that of the control (IMPA, 1988). Except for variety MY 55-14, which had 12.64\% sucrose, the other varieties surpassed the average sucrose content (13\%) for the zone supplying the El Modelo refinery (PRONAC, 2009).

The sucrose content in varieties Mex 91-662 and JA 64-20 surpassed that for the control varieties (Figure 2). However, variety JA 64-20 had the lowest yield. In contrast, variety Mex 91-662 had one of the highest yields, reflecting its high agroindustrial potential in the study zone.

\subsection{The Importance of Germplasm Banks in Sugar Refineries}

The usage of new sugar cane varieties is a common practice in the sugar refineries. The reasons for this depend mainly on the fact that the varieties currently used become susceptible to climatic, edaphic and pathogenic changes. Therefore, genetically improved varieties that can be adapted to the referred changes are required so as to improve the agroindustrial yields (Herrera et al., 2011). In that respect, Mejía (1993) pointed out that the traditional procedure for sugar cane genetic improvement is by hybridization and selection. This author also indicated that it is important to locate the genetic improvement plots in areas of sugar cane production where the crossbreeding can be carried out. However, the sugar cane flowering is not a common process because it depends on the clone genetics, climate and altitude. In Mexico the natural environmental conditions that induce the sugar cane flowering occur in Tapachula, Chiapas (Leal, 1993). Once the crossbreeding seed or clones from foreign countries are available, the selection process in situ begins in germplasm banks located near by the production area. Such banks must be continually provided with new vegetative material and seed, in order to accomplish an 
intensive selection process, which is going on until high genetic potential varieties are obtained, i.e., high agroindustrial productive varieties resistant to pest and diseases (Herrera et al., 2011). The implementation of these germplasm banks is not a common practice in the sugar refineries of Mexico. Therefore, it must be considered as a strategic activity to ensure a continuous supply of new varieties of sugar cane under a phytosanitary control, which may contribute to a more sustainable agricultural development of the sugar refineries.

\section{Conclusions}

In this agroindustrial evaluation of sugarcane varieties and their harvesting cycles, carried out during the planting and ratoon cycles, we observed initial tendencies in their genetic expression; differences among cycles were found for yield and sucrose content. Varieties L 73-65 and Mex 91-662 showed better yield and sucrose content in the two production cycles studied.

Given that the yields obtained in both cycles are superior to the average yield for the zone supplying the El Modelo refinery $\left(100 \mathrm{t} \mathrm{ha}^{-1}\right)$, most of the varieties studied represent an important bank of germplasm that must be submitted to the phases or processes of multiplication III and semi-commercial evaluation before being subjected to variety diversification in the sugarcane zones supplying the factories for Veracruz and other states in Mexico.

Finally, this study is one of the first of its type in the sugarcane zones of Veracruz, and contributes important information for the diversification of varieties in this crop, leading to increases in the agroindustrial yield in this state and in Mexico.

\section{Acknowledgements}

To Consejo Nacional de Ciencia y Tecnología (CONACyT) for the economic assistance to acquire technical help for this project. To C.B.T.a. No. 17 for the facilities used during this investigation. To Colegio de Postgraduados Campus Veracruz ("LPI8 Impacto y Mitigación del Cambio Climático") for financial support and to Ing Juan Manuel Hernández Pérez for assistance in the preparation of some figures.

\section{References}

Díaz, A., Rea, R., De Sousa, O., \& Briseño, R. (2003). B80-408 y B80-509: Nuevas Variedades promisorias de caña de azúcar en Venezuela. Caña de Azúcar, 21(1), 3-16.

Flores Cáceres, S. (2001). Las Variedades de Caña de Azúcar en México (Ed.), ATAM. México, D.F.

Flores, C. G., Castrejón, P. F. A., Olivos, A. P., Aviles, N. J. N., Lorenzana, M. A. V., Rosales, G. G., \& Paredes, H. S. (2011). Composición nutrimental de 12 variedades de Pennisetum purpureum con 9 semanas de rebrote. XLVII Reunión Nacional de Investigación Pecuaria (p. 178). León, Guanajuato 2011.

Fonseca, D., Mario Ernesto., F., Resendiz, H., \&Michel, L. J. L. (2006). Evaluación agroindustrial de variedades prometedoras de caña de azúcar (Saccharum officinarum L.) en la zona del Ingenio Tala. Avances en la investigación científica en el CUCBA (p. 217). Universidad de Guadalajara, Jalisco.

Herrera, S., Milanés, A. N., Ordóñez, R. P., Mesa L. B. J. M., Enríquez V., Castillo, R. A., ... Tinoco, D. A. J. (2011). Estimados preliminares de rendimiento de campo a partir de variables de suelo y clima en el ingenio Motzorongo S.A. de C.V., Veracruz, México. Revista Cuba \& Caña. Cuba.

IMPA [Instituto para el Mejoramiento de la Producción de Azúcar]. (1988). Programa de Variedades. Metodología Experimental (pp. 1-59). México O.E.

ISO [International Sugar Organization] (2011). Quarterly Market Outlook (p. 73), November 2011. London.

Julca, B., y Fava Neves Marcos, B. (2011). Caracterización de sistemas agroindustriales: Un estudio comparativo de los sectores sucroenergéticos de Brasil y Colombia. Interciencia, Mayo, 356-364.

Leal, P. R. J. (1993). Generación de variedades de caña en el ingenio Tres Valles. In D. Riestra D., S. Picharco H., M. Marín G., y L. E. Zedillo P. de L. (Eds.), La Capacitación y Desarrollo Tecnológico en el Campo Cañero Mexicano. Memoria del Simposio Nacional. Tomo 2. Xalapa, Veracruz,. México (pp. 417-422).

Mejía, C. A. (1993). Mejoramiento genético de cultivos clonales (caña de azúcar). In La Capacitación y Desarrollo Tecnológico en el Campo Cañero Mexicano. Memoria del Simposio Nacional. Tomo 2. Xalapa, Veracruz,. México. D. Riestra D., S. Picharco H., M. Marín G., y L. E. Zedillo P. de L. (eds) (pp. 367-373).

Olivares Sáenz, E. (1996). Paquete de diseños experimentales, versión 2.5. Facultad de Agronomía UANL, Marín N.L., México. 
Oviedo, M. R., Durán, J., \& Barrantes, J. C. (1999). Determinación de la curva de madurez de nueve variedades de caña de azúcar, en Pérez Zeledón, Costa Rica. Dirección de Investigación y Extensión de la caña de azúcar (DIECA-LAICA) (p. 277). XI Congreso Nacional Agronómico.

PRONAC [Programa Nacional de la Agroindustria de la Caña de Azúcar]. (2007). Secretaria de Agricultura, Ganadería, Desarrollo Rural, Pesca y Alimentación. Retrieved from http://w4.siap.gob.mx/sispro/SP_AG/cania/cania/docs/r_pronac.pdf

PRONAC [Programa Nacional de la Agroindustria de la Caña de Azúcar]. (2009). Digitalización del Campo Cañero en México para Alcanzar la Agricultura de Precisión de la Caña de Azúcar. Ingenio El Modelo. www.sagarpa.gob.mx. (Consulted: 27-07-08).

Rea, R., \& De Sousa, V. O. (2001). Interacción genotipo x ambiente y análisis de estabilidad de ensayos regionales de caña de azúcar en Venezuela. Caña de Azúcar, 19, 3-15.

Rubio, I. J. F. (1997). Evaluación y selección de variedades. In II Curso-Taller Variedades de Caña de Azúcar. ITA No. 18 y Universidad Veracruzana (p. 114). Veracruz.

SAGARPA [Secretaria de Agricultura, Ganadería, Desarrollo Rural y Pesca]. (2009). Servicio de información y estadística agroalimentaria y pesquera. Anuario estadístico de la producción agrícola 2009. Retrieved from http://www.sagarpa.gob.mx/agronegocios/Estadisticas/Documents/VERACRUZ.pdf

Sánchez Fuentes, M. (1997). Desarrollo de la producción de caña y azúcar en la República mexicana. Colegio de Postgraduados (p. 143). México.

Zérega, M. L. O., Rojas, A. L., \& Hernández, A. T. L. (2002). Caracterización y sugerencias de manejo de los recursos agroecológicos para la producción de caña de azúcar en la Unión de Prestatarios La Esperanza, estado Yaracuy. Revista Caña de Azúcar, 20(1), 18-40. 